УДК 903.02

\title{
ОБ ОДНОЙ ГИПОТЕЗЕ В СВЯЗИ С ПРОИСХОЖДЕНИЕМ ГОНЧАРСТВА
}

\author{
(C) 2020 Ю.Б. Цетлин \\ Институт археологии Российской академии наук, г. Москва \\ Статья поступила в редакцию 24.09.2020
}

\begin{abstract}
В статье на основе длительных экспериментов, этнографических и археологических данных обсуждается гипотеза о происхождении форм глиняной посуды на основе приемов первобытной кулинарии. Проведенные эксперименты показывают, что в результате приготовления в очаге мясной пищи, обмазанной глиной специального состава, возможно получение полностью сохранившейся глиняной емкости, которая могла быть прототипом первых форм сосудов. Это предположение косвенно подтверждается результатами специального изучения древнейшей керамики памятников Приамурья. В статье высказывается предположение, что первые глиняные сосуды использовались для приготовления на огне горячей пищи в ритуальных целях.

Ключевые слова: происхождение гончарства, эксперимент, этнография, обжиг сосудов, приготовление пищи, древнейшая керамика Приамурья.
\end{abstract}

DOI: $10.37313 / 2658-4816-2020-2-4-122-134$

Статья подготовлена в рамках государственного задания № АAAA-A18-118011790092-5.

\section{Введение. Постановка проблемы}

В археологической литературе неоднократно высказывалось мнение о том, что возникновение гончарства было полицентрическим процессом ${ }^{1}$, т.е. оно неоднократно возникало в разных регионах Земного шара, в разных природно-климатических и культурно-хозяйственных условиях. Вероятно, в зависимости от конкретных условий места и времени, и пути возникновения гончарства были неодинаковы. Пока достоверно можно говорить о двух таких центрах. Один из них находился на Ближнем Востоке, другой - в Юго-Восточной Азии, включая, вероятно, Дальний Восток Россииㄹ․

Помимо этого, влитературе высказывались разные теории о ходе этого процесса. Наиболее старой, возникшей еще в XVIII в., была так называемая «корзиночная» теория. Она опиралась на единичные этнографические свидетельства и отчасти получила дополнительное

$\overline{Ц е т л и н ~ Ю р и и ̆ ~ Б о р и с о в и ч, ~ д о к т о р ~ и с т о р и ч е с к и х ~}$ наук, ведущий научный сотрудник Отдела теории и методики Института археологии РАН.

E-mail: yu.tsetlin@mail.ru подтверждение данными лингвистики ${ }^{3}$. Хотя корзиночная теория происхождения гончарства неоднократно подвергалась убедительной критике, ссылки на нее можно встретить в специальной литературе ${ }^{4}$.

В 1980-90-е гг. новая теория происхождения гончарства была сформулирована А.А. Бобринским ${ }^{5}$. Опираясь на этнографические, археологические и экспериментальные данные, он выделил в истории гончарства так называемую «догончарную» стадию, которая характеризовалась изготовлением сосудов из смеси глины и органических материалов (прежде всего, помета птиц и навоза животных), причем доля этих органических материалов в составе формовочной массы превышала или была примерно равна доле самой глины. Самым важным выводом этой теории было то, что, как показали многочисленные эксперименты, сосуды, изготовленные из смеси глины и помета птиц в большой концентрации, можно было использовать для приготовления горячей пищи без предварительного обжига. Это было связано с открытым А.А. Бобринским 
явлением «самоцементации» глинистых частиц под влиянием химических компонентов, входящих в состав помета птиц 6

Позднее благодаря совместным исследованиям А.А. Бобринского и И.Н. Васильевой эта теория подверглась корректировке ${ }^{7}$. В частности, ими было установлено, что во многих регионах Восточной Европы наиболее ранняя неолитическая керамика изготавливалась не из смеси глины и органических материалов, а из так называемого «глиноподобного» пластичного сырья, в качестве которого выступали различные озерные и речные илистые отложения. Основной чертой этих отложений было присутствие в них большого количества водной растительной и животной органики, обломков раковин моллюсков, мелких косточек и чешуи рыб. Некоторые виды илов, распространенные главным образом в предгорных районах, содержали, напротив, небольшое количество органического материала, но зато в них в изобилии присутствовал слабоокатанный или остроугольный песок разного размера. Благодаря такому сложному природному составу и «равнинные», и «горные» илы могли не только использоваться для изготовления сосудов, но и подвергаться целенаправленному обжигу. Особенно важным было то, что они не требовали для этого введения каких-либо искусственных органических или минеральных примесей. Массовое использование илов и грубых суглинков для изготовления сосудов было зафиксировано также по древнейшей керамике Дальнего Востока 8 .

Все эти разработки касались главным образом технологической стороны возникновения гончарства: вида пластичного сырья, его состава и термической обработки. Однако вторая сторона этого процесса (возникновение формы сосуда) до сих пор остается очень слабо изученной. На основании многочисленных этнографических данных высказывается, вероятно, правильное общее мнение, что форма глиняных сосудов на первых этапах копирует форму более ранних неглиняных (каменных, деревянных, плетеных и иных) емкостей‥ От- крытие широкого использования илистого сырья в древнем гончарстве вновь вызвало обращение к экспериментам с обмазыванием илом плетеных емкостей. Такие эксперименты проводились И.Н. Васильевой, причем илом или глиной обмазывались внешняя, внутренняя и обе поверхности корзин из рогоза. Затем они подвергались обжигу в кострище. После обжига целиком сохранились сосуды из ила и глины, для изготовления которых корзины использовались как формы-емкости ${ }^{10}$.

В настоящей статье предметом рассмотрения станет еще один аспект проблемы возникновения гончарства, занимающий как бы промежуточное положение: с одной стороны, он относится к области гончарной технологии, а с другой - к форме сосуда. Суть его состоит в следующем.

По этнографическим данным хорошо известны факты приготовления мясной пищи путем запекания в ямах. Для этого сооружалась яма нужного размера с плоским дном. В ней разводился костер, потом на угли укладывалось мясо, обернутое листьями. Оно засыпалось золой, поверх которой разводился костер. Запекание длилось всю ночь ${ }^{11}$. Еще более интересный факт касается примитивных охотников, которые (как и современные туристы) готовили мясо и рыбу на углях в очагах, предварительно обмазывая пищу слоем глины ${ }^{12}$. В результате под действием температуры глиняный панцирь частично обжигался, а мясо или рыба запекались и были пригодны к употреблению. Совершенно так же современные хозяйки запекают мясо в духовке, только используют при этом вместо глины металлическую фольгу или плотную бумагу.

В современной науке преобладает мнение, и, судя по всему, оно правильное, что «изобретателями» гончарства были женщины. В пользу этого говорит тот факт, что у наиболее примитивных народов, которые были знакомы с этим производством, оно находилось в руках именно женщин. Также в абсолютном большинстве случаев женщины занимались и приготовлением пищи. Устойчивое сочетание этих двух фактов у 
разных народов, в том числе находящихся на достаточно низком уровне экономического развития, позволяет предполагать, что по крайней мере в некоторых районах Земного шара происхождение гончарства могло быть связано с кулинарной деятельностью женцин (о такой возможности ранее писал А.А. Бобринский $\left.{ }^{13}\right)$.

Предлагаемая к рассмотрению гипотеза состоит в том, что в обществе охотников и собирателей лесной зоны в первобытную эпоху могла иметь место практика приготовления мясной пищи (главным образом, вероятно, дичи), обмазанной глиной, в углубленных в землю очагах. При правильно подобранном составе глинистого материала и соблюдении определенных режимов термической обработки в результате такой операции глиняный «панцирь» мог обжигаться и сохранять свою целостность после извлечения из него запекаемой дичи. В результате возникал практически готовый сосуд, хорошо обожженный с внешней стороны и готовый по крайней мере потенциально к использованию в быту в качестве емкости для последующего приготовления горячей пищи на открытом огне.

\section{Описание экспериментов и полученных на их основе выводов}

В течение четырех лет (2017-2020) на базе Самарской экспериментальной экспедиции по изучению древнего гончарства (руководители - Н.П. Салугина и И.Н. Васильева) мною совместно с Е.В. Волковой проводились эксперименты по моделированию описанного выше способа приготовления мясной пищи.

При организации эксперимента мы опирались, во-первых, на этнографические данные о примитивных режимах обжига сосудов $^{14}$, во-вторых, на опыт, накопленный нами в ходе предшествующих экспериментов по обжигу сосудов, в-третьих, на результаты изучения технологии изготовления древнейшей глиняной посуды.

\section{Основные правила организации эксперимента}

Для эксперимента во всех случаях ис- пользовался углубленный в землю очаг глубиной около 40-50 см и диаметром 100-140 см. На дне очага создавалась платформа из дерева (использовались либо сучья диаметром 2-3 см, либо плоские деревянные плашки). Эти плашки покрывались слоем свежих листьев для того, чтобы предотвратить просыпание золы сквозь дерево платформы, т.к. это воспрепятствовало бы ее горению. Листья покрывались слоем холодной золы толщиной 1-2 см, на который укладывалась курица, обмазанная слоем формовочной массы определенного состава (в ходе экспериментов испытывались разные варианты состава формовочной массы). Панцирь делался бессистемным лоскутным налепом. Затем он обкладывался древесным топливом в виде неширокого «колодца», в который засыпалась зола, покрывавшая «панцирь» слоем толщиной 5-7 см. После этого все сооружение с боков и сверху вновь покрывалось древесным топливом. Затем на дне очага по периметру сооружения укладывались тонкие сухие ветки, которые поджигались по возможности одновременно. Следом за ветками начинали гореть дрова. По мере прогорания по периметру подкладывались новые дрова. Слой золы, покрывавший «панцирь» с курицей, предохранял его от прямого контакта с огнем, создавая при обжиге восстановительную среду. В общей сложности эксперимент продолжался от 3 до 5 часов.

\section{Описание конкретных экспериментов и полученные выводы}

За 4 года было проведено 6 экспериментов: 2 - в 2017 г., 2 - в 2018 г., 1 - в 2019 г. и 1 - в 2020 г.

Эксперимент № 1. Этот эксперимент проводился в 2017 г. в Самарской экспериментальной экспедиции по изучению древнего гончарства. В этом году работа экспедиции была переведена из поселка Прибрежный (Самарская область) на территорию спортивного лагеря «Юность» Самарского государственного социально-педагогического университета. Поскольку на 
территории лагеря еще не была подготовлена специально оборудованная рабочая площадка для изучения обжига глиняных сосудов, для эксперимента пришлось использовать металлический мангал с увеличенной высотой стенок. Бройлерная курица весом 1,5 кг была обвязана шпагатом, обмотана марлей, а затем обмазана слоем природной илистой глины без искусственных добавок. Топливом служили сучья и ветки. Из-за того, что обжиг проводился в мангале, нельзя было фиксировать температуру с помощью термопары. Обжиг длился в течение 3 часов. Панцирь снаружи весь потрескался, а внутри был совершенно сырым. Однако курица хорошо запеклась. Эксперимент признан неудачным, т.к. панцирь не сохранился.

Эксnеримент № 2. Был проведен в 2017 г. на старом месте работы экспедиции в поселке Прибрежный, где параллельно проводился обжиг сосудов и экспериментальных образцов в горне и в очаге. Курица была обмотана бинтом, затем обмазана слоем запесоченного речного ила без искусственных добавок (илл. 1). Эксперимент проводился в углубленном в землю очаге с использованием сосновой коры в качестве топлива, горение длилось 5 часов (илл. 2). В связи с

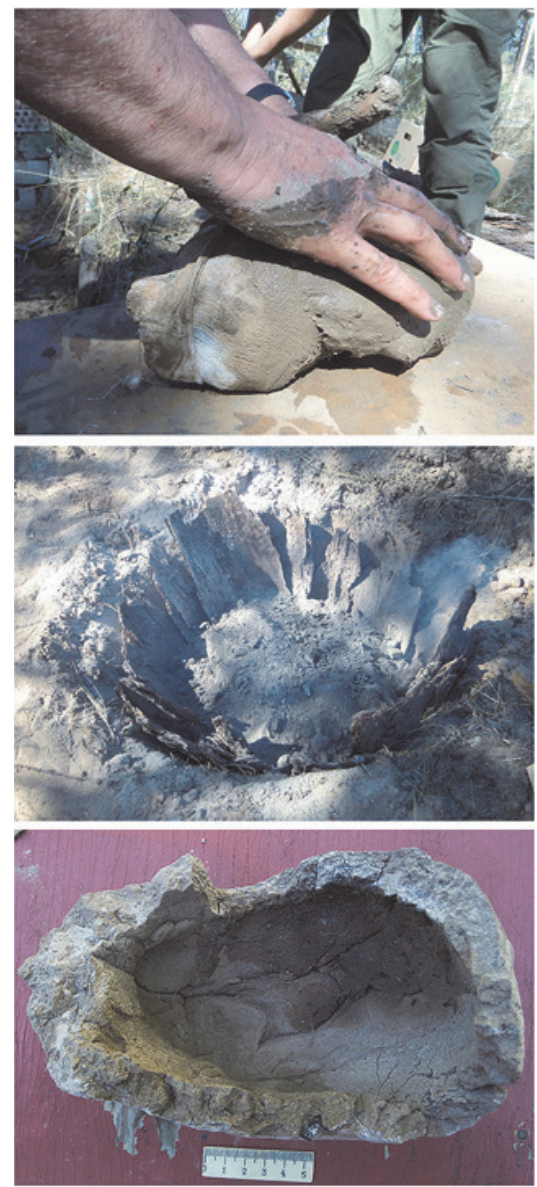

Илл. 1. Эксперимент № 2.

Курица обматывалась бинтом, обмазывалась запесоченным речным илом и запекалась под слоем золы. Топливо - сосновая кора.

Сохранившаяся половина панциря



Илл. 2. Эксперимент № 2. График изменения температуры от времени 

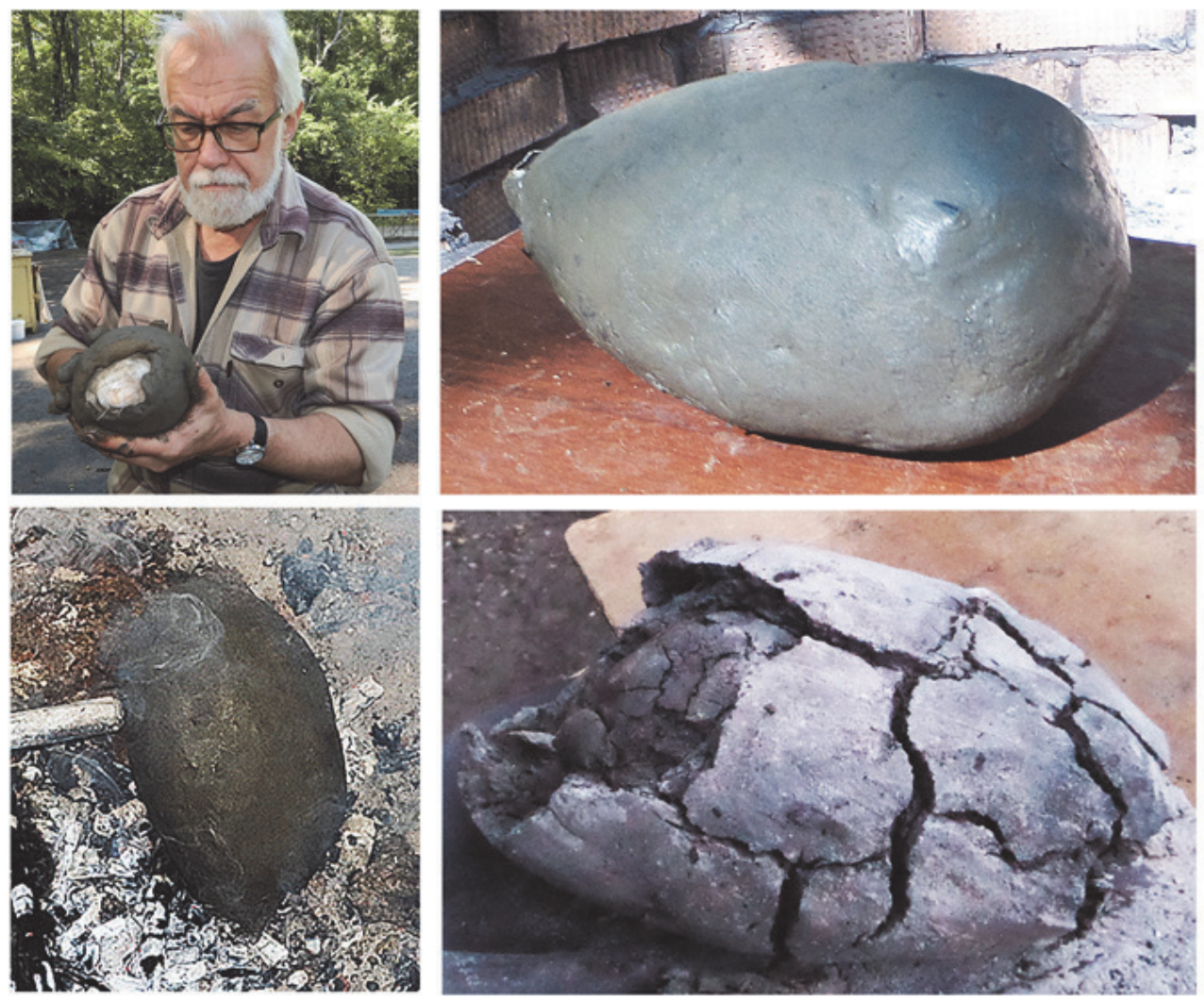

Илл. 3. Эксперимент № 3. Курица обматывалась бинтом, обмазывалась речным илом с естественной органикой, запекалась в золе. Топливо - дрова.

Панцирь полностью разрушился

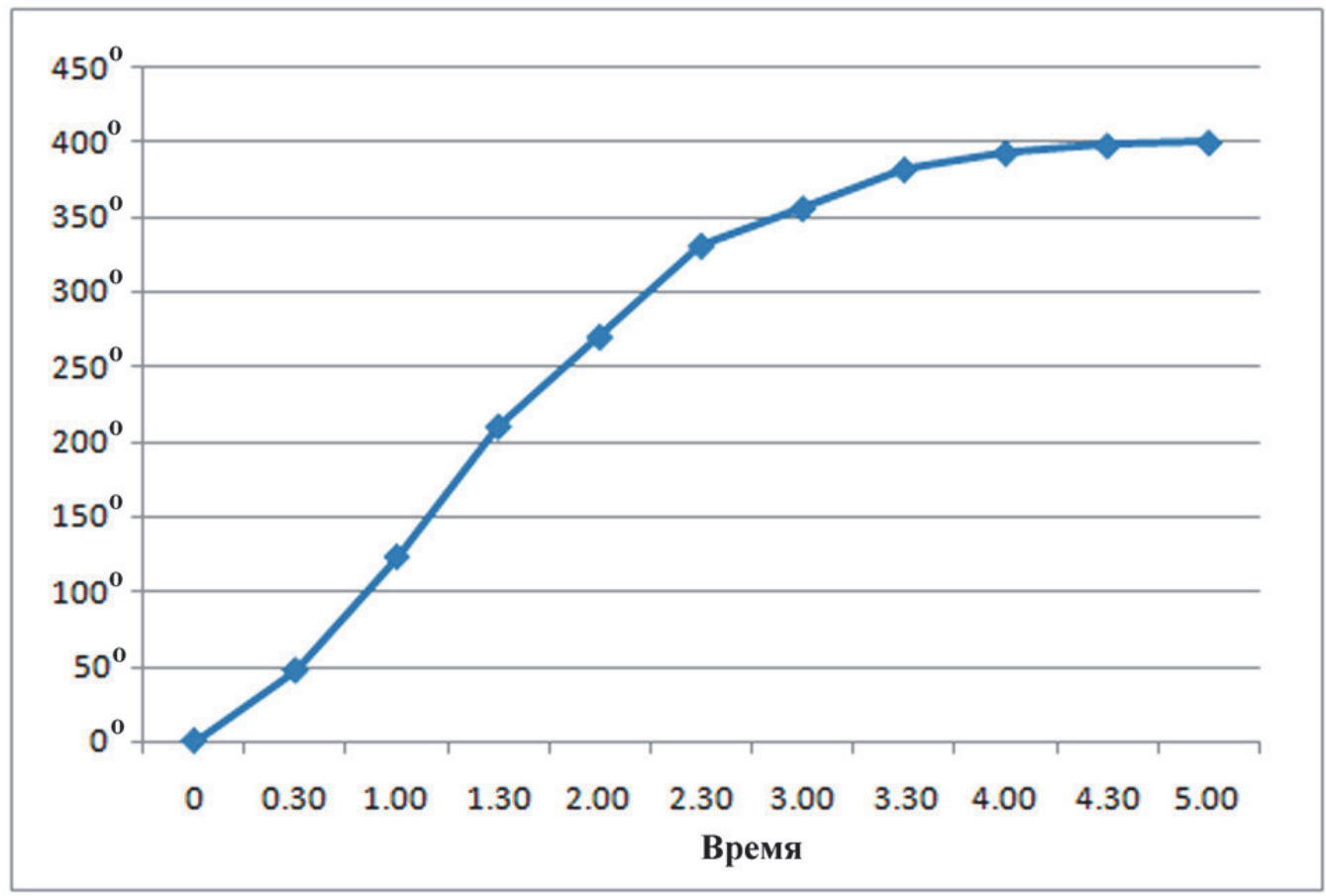

Илл. 4. Эксперимент № 3. График изменения температуры от времени

высокой теплоемкостью сосновой коры по сравнению с чисто древесным топливом в очаге была получена температура начала каления глины и, судя по цвету панциря, образовалась полувосстановительная газовая среда. Верхняя его часть вся была в тре- 
щинах, но частично сохранилась, а нижняя осталась практически не обожженной. Эксперимент признан неудачным.

Эксперимент № 3. В 2018 г. в лагере «Юность» была оборудована специальная рабочая площадка для изучения обжига, на которой располагались кострище, два очага (углубленный в землю и наземный из кирпичей) и гончарный горн. Эксперимент проводился в очаге, углубленном в землю. Для создания панциря использован богатый природный органикой речной ил без искусственных добавок (илл. 3). Горение продолжалось в течение 5 часов (илл. 4), в качестве топлива использованы дрова. В результате панцирь распался на мелкие кусочки, курица обуглилась и высохла, к еде не пригодна. Эксперимент признан неудачным.

Эксперимент № 4. Проводился в углубленном очаге в лагере «Юность». Для изготовления панциря использована формовочная масса из смеси речного ила и мелкого речного песка в концентрации 1:3. Продолжительность горения 3 часа 10 мин. Ввиду неисправности термопары измерение температуры не проводилось. В результате панцирь весь распался, но курица запеклась хорошо и не подгорела. Эксперимент также признан неудачным.

Эксперимент № 5. Проводился в 2019 г. в углубленном очаге в лагере «Юность». Для эксперимента была использована неощипанная курица вместе с перьями (илл. 5). Панцирь сделан из смеси природной глины и влажного навоза коровы в концентрации 1:1. В качестве топлива использовалось дерево. Горение длилось 3 часа 45 мин. Из-за сырой прохладной погоды температура была очень неустойчива (илл. 6). Весь глиняный панцирь с внешней стороны был покрыт трещинами, которые шли в разных направлениях. Однако, как выяснилось, они были не сквозные. Когда панцирь разделился поперек на две половины, стало понятно, что перья глубоко впечатались в глину и сохранились полностью. Это помешало извлечь курицу из панциря. Одна сторона панциря (на кото- рой он лежал) была плоская, другая - выпуклая. Плоская сторона практически не обожглась, глина сырая. Верхняя, более тонкая, сторона обожжена. Образцы панциря из верхней и нижней частей испытаны на остаточную пластичность. Образец из нижней части полностью сохранил остаточную пластичность, а у образца из верхней части она отсутствовала. Курица была съедобной. В целом данный эксперимент можно считать более удачным.

Эксперимент № 6. Проводился в 2020 г. в углубленном очаге в лагере «Юность». Курицу без перьев обернули крапивой со стеблями и завязали шпагатом (илл. 7). Панцирь изготовлен двухслойным лоскутным налепом из формовочной массы, состоящей из природной глины средней пластичности, в которую добавлен мелкий речной песок в концентрации 1:1. Такой состав формовочной массы, судя по моим предыдущим экспериментам ${ }^{15}$, почти полностью исключал усадку панциря при сушке и обжиге. Песок предварительно замачивался на два часа, а готовую формовочную массу вылеживали в течение 9 дней. Курица и панцирь располагались вертикально, причем в нижней части панциря было оставлено специальное отверстие для стекания жира и влаги. В земляном очаге сделали платформу из деревянных плашек в один слой, на нее положили сырые листья орешника (2 см), которые засыпали тонким слоем холодной золы. Посреди платформы в землю вбили деревянный колышек и на нем вертикально установили курицу так, чтобы отверстие в панцире было с нижней стороны. По сути дела, панцирь располагался в очаге своей донной частью вверх. Вокруг панциря соорудили колодец из плашек, который весь засыпали горячей золой и угольками. Затем колодец обложили еще слоем дров и подожгли. Горение длилось 4 часа при устойчивом росте температуры с сохранением восстановительной газовой среды (илл. 8).

В результате выяснилось, что глиняный панцирь объемом около 3 литров сохранился практически полностью (илл. 7). Толь- 

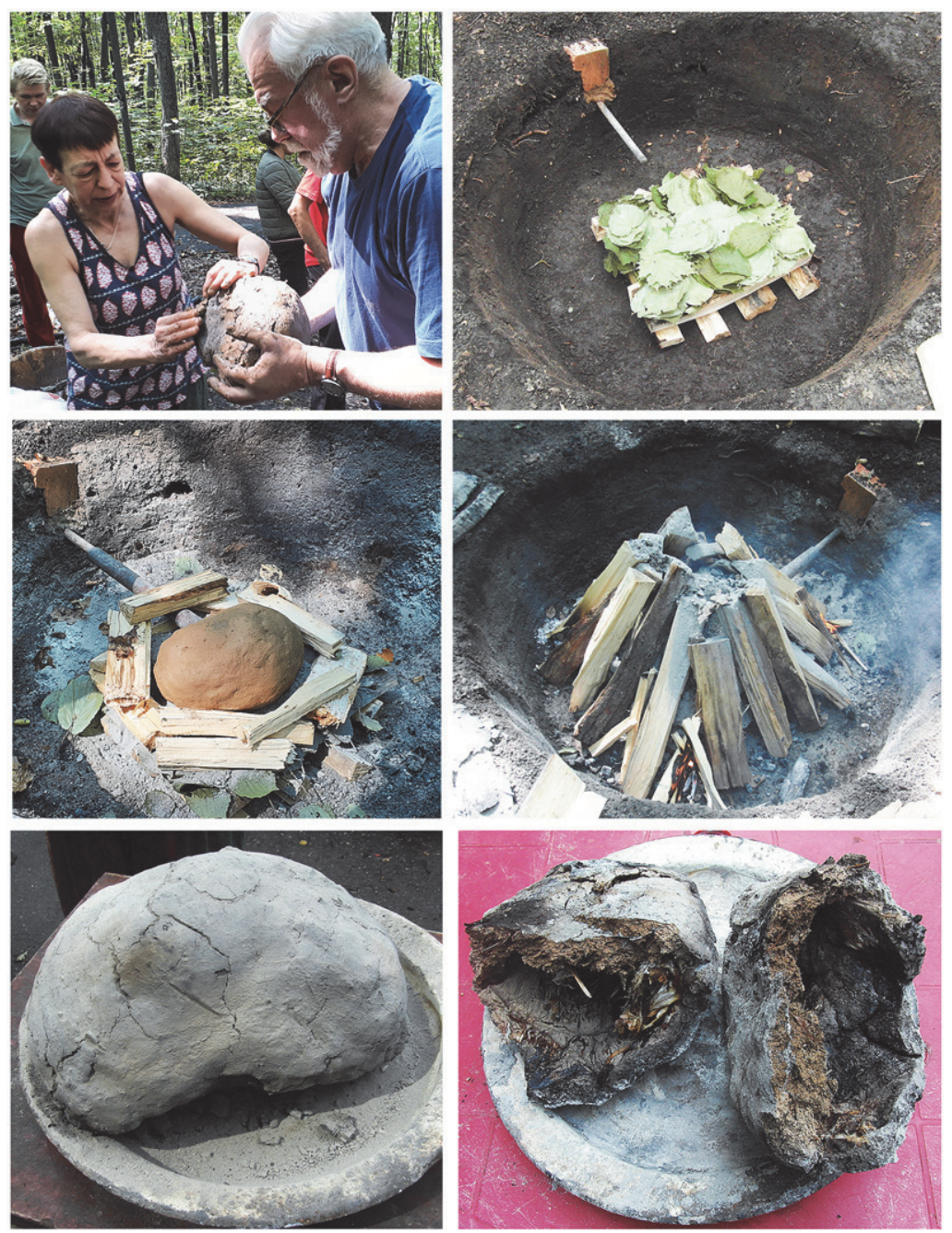

Илл. 5. Эксперимент № 5. Курица с перьями обмотана бинтом и обмазана формовочной массой из смеси глины и навоза, запекалась в золе. Топливо - древесное.

Панцирь сохранился, но имеет несквозные трещины

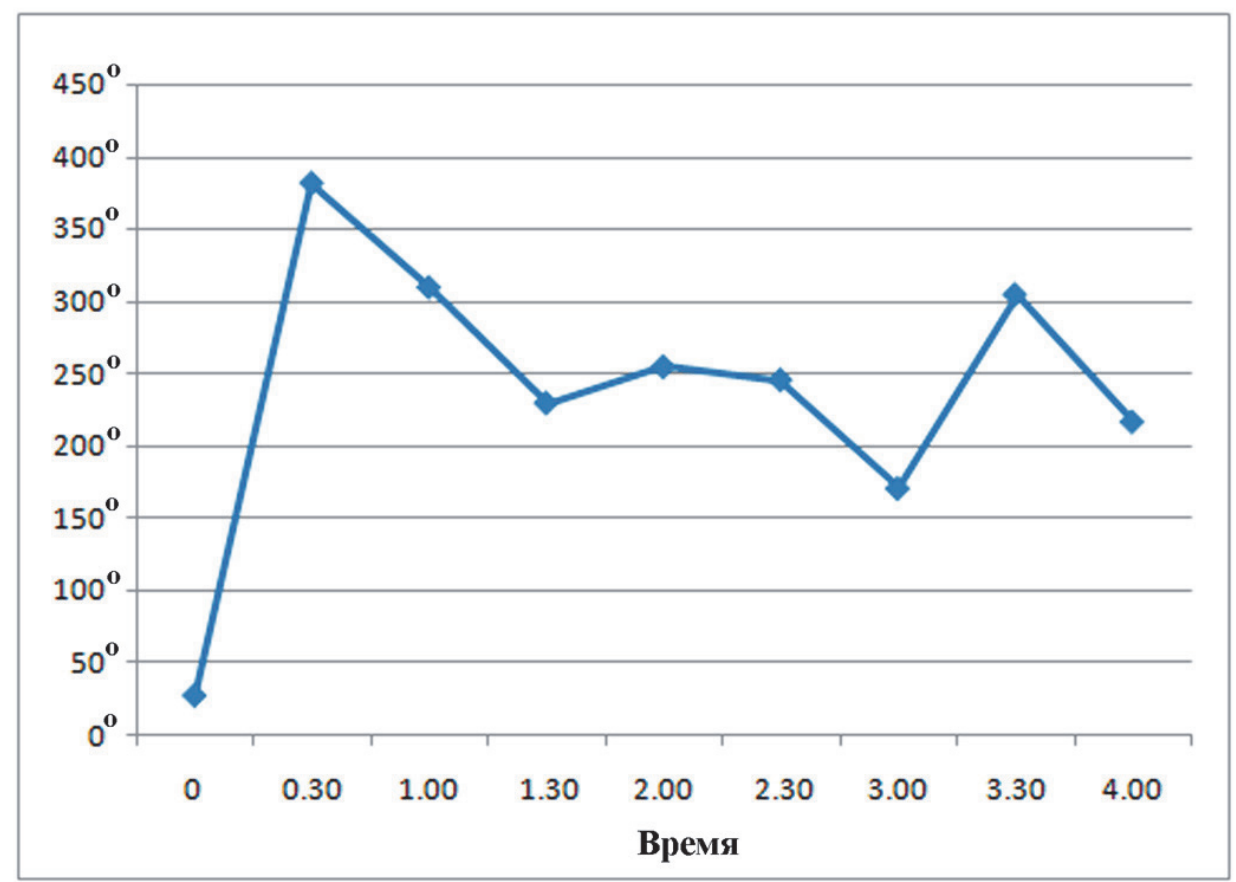

Илл. 6. Эксперимент № 5. График изменения температуры от времени 


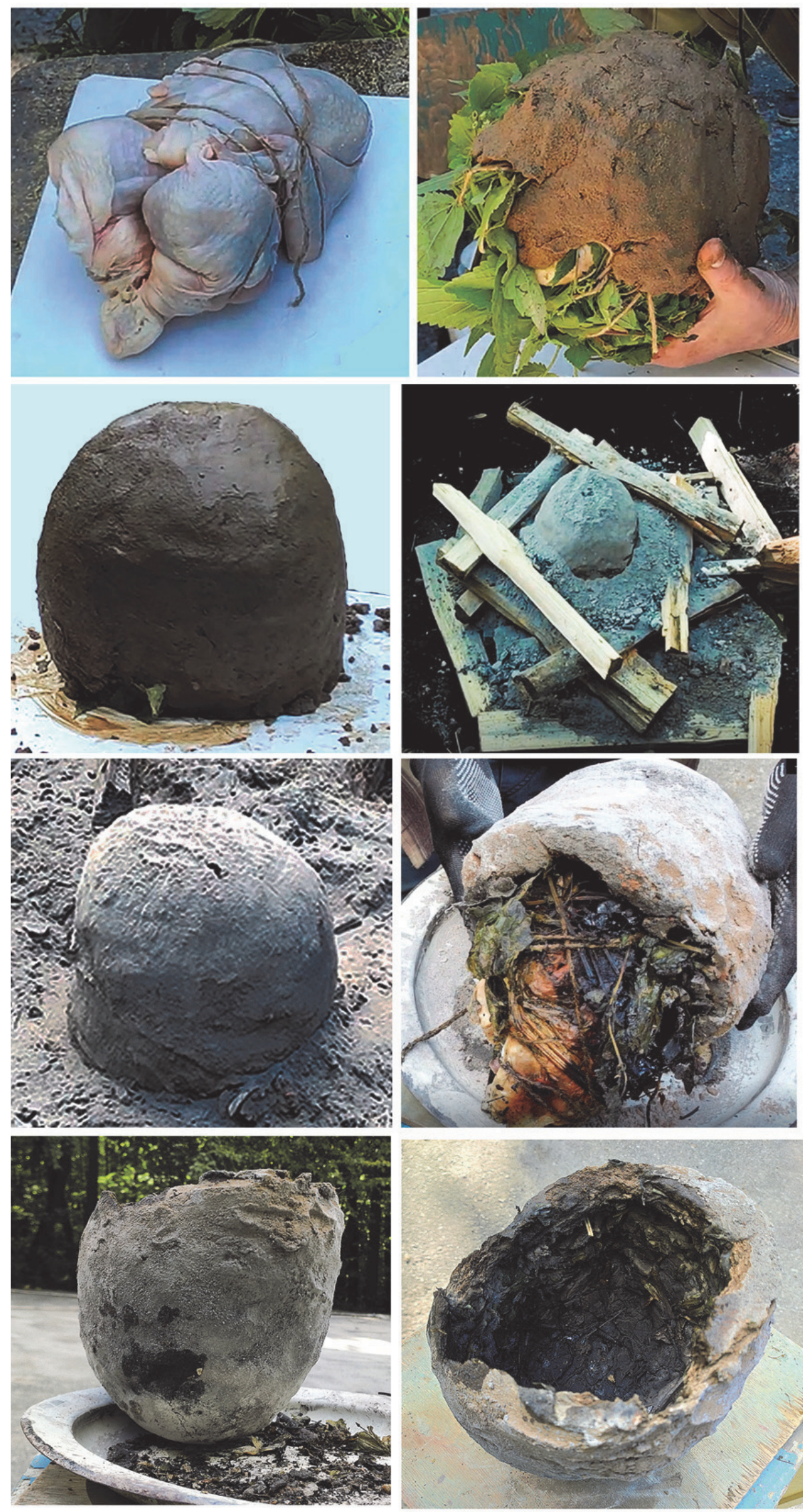

Илл. 7. Эксперимент № 6. Курица обмотана шпагатом, обернута слоем крапивы, также закрепленном шпагатом, обмазана формовочной массой из смеси глины и песка в большой концентрации, запекалась в золе.

Топливо - древесное. Панцирь сохранился практически полностью 


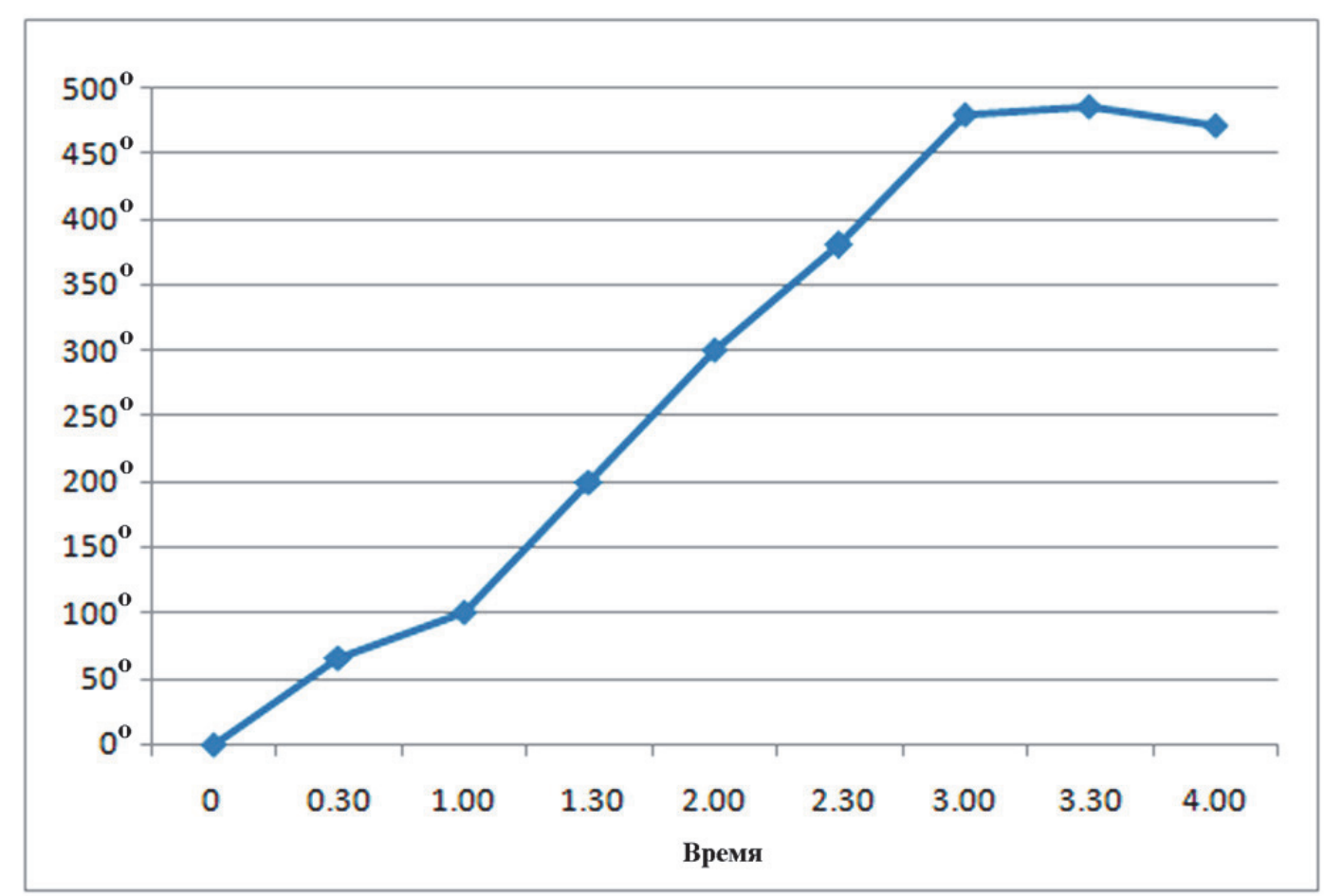

Илл. 8. Эксперимент № 6. График изменения температуры от времени

ко в верхней части панциря образовалось небольшое отверстие диаметром 4-5 мм, пробитое концом толстого стебля крапивы. После извлечения курицы из панциря образовавшаяся в результате термической обработки форма не разрушилась. Два образца испытаны на остаточную пластичность: у образца из верхней (донной) части остаточная пластичность отсутствует полностью, а у образца из нижней (венчик) части остаточная пластичность сохранилась полностью. Большая часть курицы оказалась съедобной. Поскольку емкость полностью сохранилась, данный эксперимент признан удачным.

Bыводы. Серия проведенных экспериментов позволила прийти к следующим выводам:

1. Широко практикуемое как в прошлом, так и сейчас охотниками и туристами запекание в очаге мясной пищи, обмазанной глиной, неизбежно ведет к разрушению глиняного панциря.

2. Для его сохранения необходимо соблюдение строго определенных правил, что невозможно без наличия у исполнителя устойчивых знаний и практических навыков.
3. Прежде всего, глиняный панцирь с мясом должен быть расположен на платформе и отделен от нее и топлива слоем золы толщиной 5-7 см для того, чтобы сохранялась восстановительная газовая среда и был исключен прямой контакт панциря с открытым огнем.

4. Подъем температуры в очаге и нагрев панциря с мясом должны происходить постепенно. Иначе термическая усадка внешней поверхности панциря при отсутствии таковой с внутренней стороны приведет к его растрескиванию и разрушению.

5. Между запекаемым мясом и глиняным панцирем важно создать упругую прокладку, которая допускала бы небольшую усадку внутреннего слоя панциря. В нашем эксперименте роль такой прокладки выполнял слой крапивы.

6. В качестве материала для обмазывания запекаемого мяса должна использоваться природная или специально приготовленная формовочная масса очень низкой пластичности, термическая усадка которой минимальна. Это позволит уберечь глиняный панцирь от разрушения. Проведенные эксперименты показали, что в ка- 
честве материала для панциря непригодны пластичная природная глина (в том числе илистая глина), богатый органическим материалом речной ил (даже в сочетании со средней концентрацией мелкого песка), малопригодной для этого оказалась формовочная масса из смеси природной глины и влажного навоза в большой концентрации. Требованию минимальной усадки при сушке и особенно обжиге отвечают либо искусственные формовочные массы, состоящие из смеси глины и большого количества песка (не менее $1: 1$ ), либо готовые природные суглинки, также содержащие большое количество минеральных включений. Как показали проведенные эксперименты, именно такого рода составы позволили получить наиболее удачный результат.

7. Таким образом, представляется правомерным сделать общий вывод о том, что получение готовых глиняных емкостей в результате приготовления пищи в очаге в принцие допустимо рассматривать как один из возможных путей возникновения древнейших форм глиняных сосудов.

\section{Сопоставление с данными археологии}

В настоящее время на территории Российской Федерации наиболее ранняя керамика происходит с территории Приамурья и относится к осиповской археологической культуре, выделенной А.П. Окладниковым и позднее исследовавшейся А.П. Деревянко и В.Е. Медведевым. Керамика осиповской культуры исследовалась Ю.Б. Цетлиным в Лаборатории «История керамики» Института археологии РАН в рамках научных проектов № 12-06-00186А и № 15-0600246, поддержанных РФФИ (руководитель - В.Е. Медведев).

В ходе анализа керамики поселения Гася, для которого имеется датировка по ${ }^{14} \mathrm{C} 12960$ \pm 120 л.н. (Ле-1781), выяснились очень любопытные детали, которые кажутся важными в связи с описанными выше экспериментами.

Во-первых, обращает на себя внимание то, что местные гончары более чем в
40\% случаев использовали для изготовления сосудов природное илистое сырье, содержащее остроугольные минеральные включения размером до 1,5-2,0 мм в концентрации примерно 1:1 (илл. 9). Причем формовочная масса не содержала никаких искусственно введенных примесей, кроме какого-то органического раствора, который использовался для приведения сырья в пластичное состояние.

Во-вторых, сосуды конструировались лоскутным налепом на форме-основе более чем в 75\% случаев, а для того, чтобы избежать прилипания ила к форме, гончары использовали прокладку из кожи, которая для крепления, вероятно, обматывалась специальным шнуром (илл. 10).

B-третьих, сосуды на поселении Гася в 80\% случаев обжигались в течение длительного времени в восстановительной газовой среде при температуре не более $505-550{ }^{\circ} \mathrm{C}$.

В-четвертых, судя по количеству обломков глиняных сосудов, найденных при раскопках как поселения Гася, так и других поселений осиповской культуры (Госян, Хумми и др.), число сосудов было очень небольшим. Исключение составляют такие памятники, как, например, Гончарка 1, где было найдено больше 2000 обломков осиповской керамики ${ }^{16}$.

Таким образом, все выявленные по древнейшей керамике характеристики полностью соответствуют описанным выше экспериментам. В частности, именно формовочная масса с большим количеством минеральных примесей в сочетании с использованием мягкой прокладки в виде слоя крапивы, обмотанной веревкой, и длительным низкотемпературным обжигом позволили в ходе экспериментов прийти к наиболее успешному результату.

Остановлюсь еще на двух моментах. Первое. Экспериментально можно считать установленным, что для сохранения глиняного панциря он должен быть изготовлен из низкопластичной формовочной массы, которая в природном состоянии существует в основном в виде либо сильнозапесочен- 


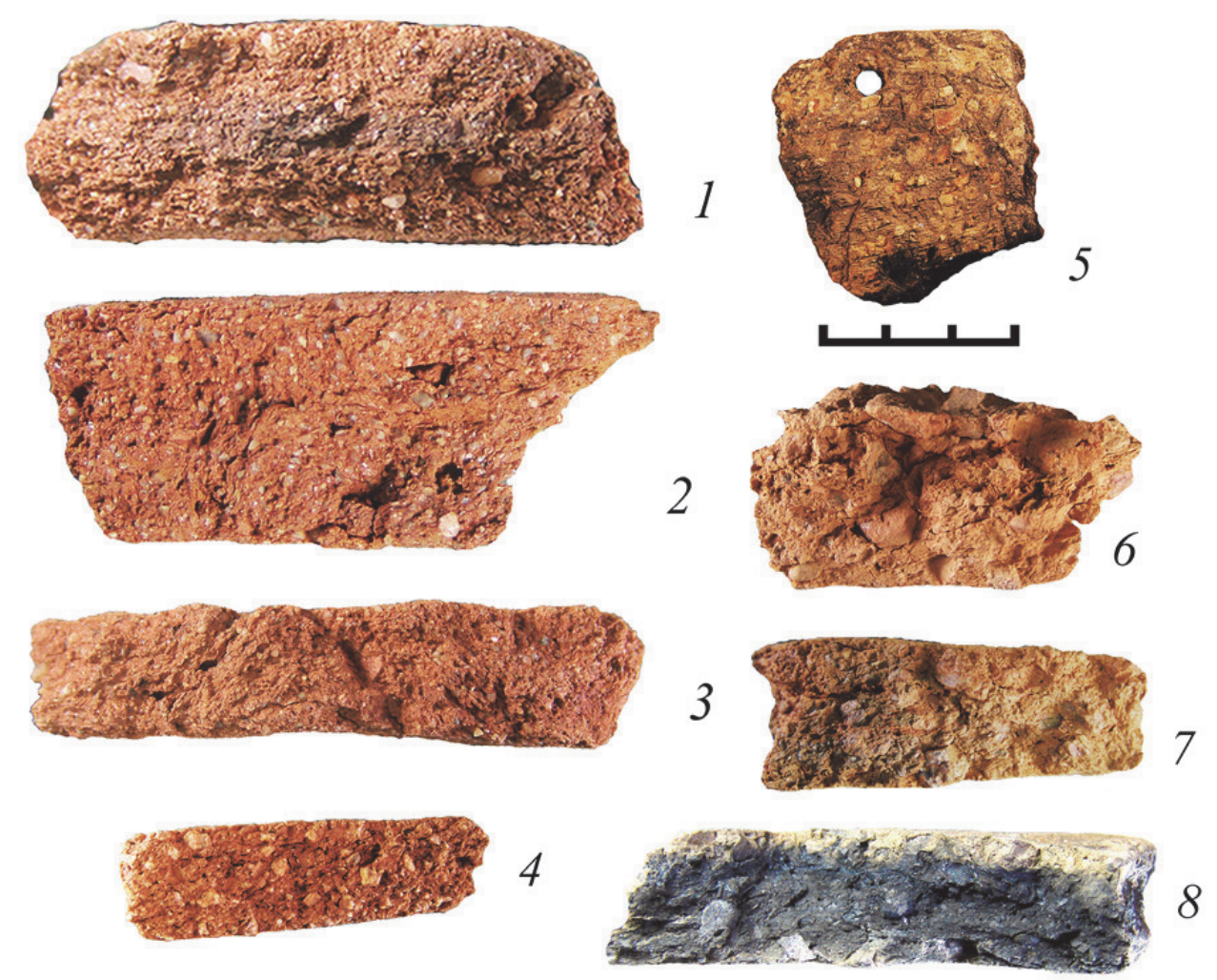

Илл. 9. Примеры готового природного сырья, из которого делалась древнейшая посуда: 1-4 - пос. Гася, горный ил с естественной примесью остроугольного песка в концентрации 1:2 - 1:1; 5-8 - грубый суглинок с естественной примесью крупных глинистых и каменистых включений в концентрации 1:3-1:2
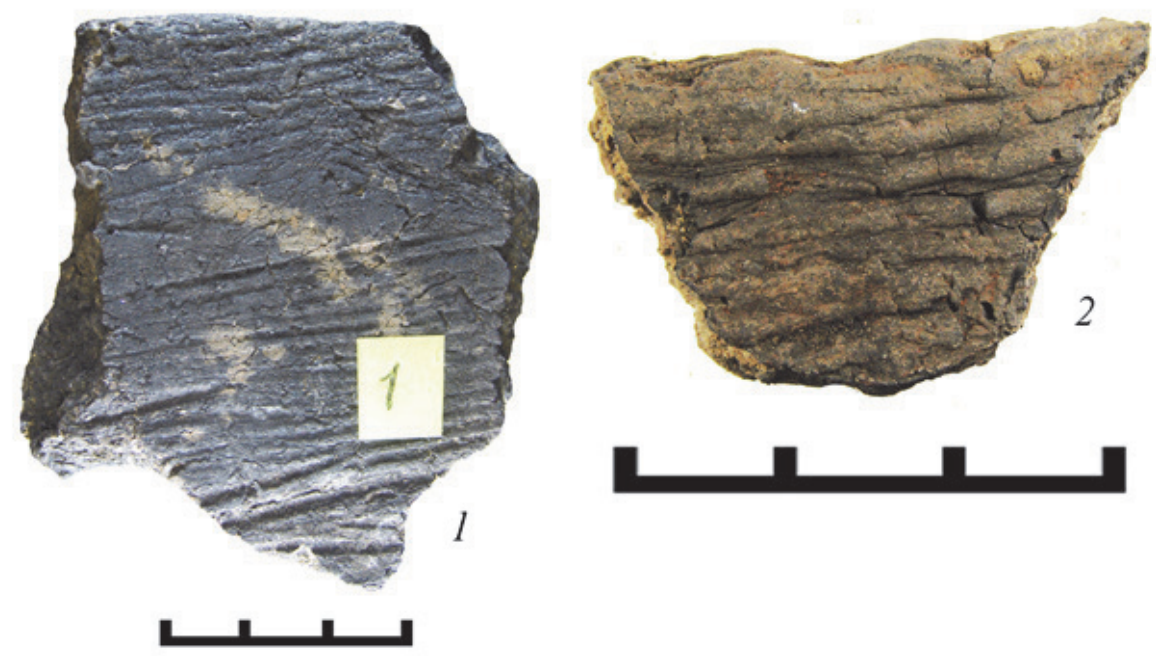

Илл. 10. Следы на внутренней поверхности осиповских сосудов, оставленные, предположительно, шнуром, которым была зафиксирована прокладка на форме-основе

ного горного ила, либо грубого суглинка с большим количеством различных крупных минеральных включений. Подобного рода природные материалы встречаются в готовом виде в основном в предгорных и горных районах. Мне они известны по кера- мике из памятников с территории Карелии, Кавказа, Алтая и Приамурья. Это позволяет высказать предположение, что в таких районах формирование гончарства может быть связано с приготовлением пищи путем обмазывания ее формовочной массой 
подобного состава. Поэтому именно в таких районах перспективны поиски соответствующих обожженных глиняных остатков, которые могут выглядеть внешне не как фрагменты керамики, а как образцы глиняной обмазки.

Второе. Судя по многочисленным этнографическим данным, в первобытную эпоху преобладало главным образом коллективное потребление пищи ${ }^{17}$. Однако сосуды с поселения Гася по своим размерам никак не могли выполнять такую функцию, поскольку в среднем их диаметр, насколько это удалось определить по дуговидности венчиков, был около 20 см, т.е. полный объем составлял не более 5-6 литров, а рабочий объем - еще меньше: примерно 4-5 литров. Несмотря на небольшой объем абсолютное большинство сосудов с поселения Гася, как удалось выяснить, использовалось как раз для приготовления горячей пищи. Исходя из вероятного коллективного потребления пищи, небольшого объема древнейших глиняных сосудов и небольшого их числа на поселении можно высказать предположение, что приготовление в них пищи на огне осуществлялось не для пропитания членов первобытного коллектива, а с какими-то сугубо ритуальными целями, для удовлетворения которых такого количества было достаточно.

В заключение еще раз подчеркну, что при современном уровне наших знаний высказанное в данной статье предположение может рассматриваться только как более или менее вероятная гипотеза, отражающая один из возможных путей происхождения древнейшего гончарства.

\section{ПРИМЕЧАНИЯ}

${ }^{1}$ Цетлин Ю.Б. Современные взгляды на происхождение гончарства // Вестник Томского государственного университета. История. Томск, 2013. № 3 (23). С. 74-80; Цетлин Ю.Б. Происхождение гончарства // Горы Кавказа и Месопотамская степь на заре бронзового века. Сборник к 90-летию Р.М. Мунчаева / Отв. ред. Х.А. Амирханов. М.: ИА РАН; 2019. С. 446-459.
${ }^{2}$ Цетлин Ю.Б., Петрова Н.Ю. Ближний и Дальний Восток: общее и особенное двух центров происхождения гончарства // Российская археология. М., 2020. № 1. С. 32-43.

${ }^{3}$ Трубачев О.Н. Ремесленная терминология в славянских языках (Этимология и опыт групповой реконструкции). М.: Наука, 1966. С. 176.

${ }^{4}$ Семенов С.А., Коробкова Г.Ф. Технология древнейших производств. Мезолит-энеолит. Л.: Наука, 1983. С. 191-192.

${ }^{5}$ Бобринский А.А. Секреты древних гончаров // Наука и жизнь. 1981а. № 10.С. 76-77; Бобринский А.А. У истоков гончарного искусства // Природа. 1981б. № 4. С. 118-119; Бобринский А.А. Происхождение гончарства // Українське гончарство. Кн. 1. Київ, 1993. С. 39-55; Бобринский A.A. О структуре и происхождении гончарной технологии // Памятники старины. Концепции. Открытия. Версии. Т. 1. СПб.; Псков, 1997. С. 9096; Бобринский А.А. Гончарная технология как объект историко-культурного изучения // Актуальные проблемы изучения древнего гончарства (коллективная монография). Самара, 1999. С. 75-104; Бобринский А.А. Данные технологии о происхождении гончарства // Вопросы археологии Поволжья. Вып. 4. Самара: Изд-во «Научно-технический центр», 2006. С. 413-421.

${ }^{6}$ Бобринский А.А. Гончарная технология как объект историко-культурного изучения // Актуальные проблемы изучения древнего гончарства (коллективная монография). Самара, 1999. С. 85-89.

${ }^{7}$ Бобринский А.А., Васильева И.Н. О некоторых особенностях пластического сырья в истории гончарства // Проблемы древней истории Северного Прикаспия. Самара, 1998. С. 193-217.

${ }^{8}$ Цетлин Ю.Б., Медведев В.Е. Гончарство осиповской культуры Приамурья (11-13 тыс. л.н.) // Современные подходы к изучению древней керамики в археологии. Международный симпозиум 29-31 октября 2013 г., Москва. М.: ИА PAH, 2015. C. 298-312.

${ }^{9}$ Цетлин Ю.Б. Современные взгляды на происхождение гончарства // Вестник Томского государственного университета. История. Томск, 2013. № 3 (23). С. 74-80; Цетлин Ю.Б. Происхождение гончарства // Горы Кавказа и Месопотамская степь на заре бронзового века. Сборник к 90-летию Р.М. Мунчаева / Отв. ред. Х.А. Амирханов. М.: ИА РАН, 2019. С. 446-459.

${ }^{10}$ Васильева И.Н. К вопросу о зарождении гончарства в Поволжье // Вопросы археологии Поволжья. Вып. 4. Самара. 2006. С. 429-431.

11 Ливингстон Д. Путешествие по Замбези и ее притокам и открытие озер Ширва и Ниасса 
(1858-1864). Т. І. СПб.; М.: Издание М.О. Вольфа, 1867. С. 192.

${ }^{12}$ Народы мира. Этнографические очерки. Народы Австралии и Океании. М.: Изд-во АН СССР, 1956. С. 107-108.

${ }^{13}$ Бобринский А.А. Данные технологии о происхождении гончарства // Вопросы археологии Поволжья. Вып. 4. Самара: Изд-во «Научнотехнический центр», 2006. С. 419.

${ }^{14}$ Drost D. Topferei in Afrika. Technologie. Akademie. Verlag, Berlin. 1967. S. 214-234.

15 Эксперименты были связаны с выяснением того, как меняется объемная усадка глины при разной концентрации в ней примеси мелкого песка. Выяснилось, что по мере уве- личения количества песка усадка образца уменьшается и при концентрации его 1:1 она равна примерно 1,5\%. Однако при введении пылевидного песка в концентрации 2:1 было обнаружено, что экспериментальный образец после обжига немного увеличился в размере. Это явление было названо «обратной усадкой».

${ }^{16}$ Шевкомуд И.Я., Яншина О.В. Начало неолита в Приамурье: поселение Гончарка-1. СПб.: МАЭ PAH, 2012. С. 148.

${ }^{17}$ Семенов Ю.И. Экономическая этнология. Первобытное и раннее предклассовое общество. Ч. 1-3. М.: Институт этнологии и антропологии PAH, 1993. C. 100-163.

\title{
ON ONE HYPOTHESIS IN CONNECTION WITH THE ORIGIN OF POTTERY
}

\author{
(C) 2020 Yu.B. Tsetlin
}

\section{Institute of Archaeology, Russian Academy of Sciences, Moscow}

\begin{abstract}
The article on the basis of long experiments, ethnographic and archaeological data discusses the hypothesis about the origin of forms of earthenware based on the techniques of primitive cooking. Experiments show that as a result of the preparation of meat food in the center, coated with clay of a special composition, it is possible to obtain a fully preserved clay container, which could be a prototype of the first forms of vessels. This assumption is indirectly confirmed by the results of a special study of the oldest ceramics of the monuments of the Amur Region. The article suggests that the first clay vessels were used to cook hot food on fire for ritual purposes.

Keywords: origin of pottery, experiment, ethnography, vessel firing, cooking, ancient ceramics of the Amur region.
\end{abstract}

DOI: $10.37313 / 2658-4816-2020-2-4-122-134$

Yuri Tsetlin, Doctor of History, Leading Researcher at the Department of Theory and Methodology of the Institute of Archaeology of the Russian Academy of Sciences.E-mail: yu.tsetlin@mail.ru 